$10-8-2021$

\title{
Case Study: The International Criminal Tribunal for the Former Yugoslavia's Court Transcripts in Bosnian/Croatian/Serbian-Part 1: Needs, Feasibility, and Output Assessment
}

Besmir Fidahić

Maastricht University

Follow this and additional works at: https://digitalcommons.usf.edu/gsp

\section{Recommended Citation}

Fidahić, Besmir (2021) "Case Study: The International Criminal Tribunal for the Former Yugoslavia's Court Transcripts in Bosnian/Croatian/Serbian-Part 1: Needs, Feasibility, and Output Assessment," Genocide Studies and Prevention: An International Journal: Vol. 15: Iss. 2: 37-48.

DOI:

https://doi.org/10.5038/1911-9933.15.2.1846

Available at: https://digitalcommons.usf.edu/gsp/vol15/iss2/6

This Case Study is brought to you for free and open access by the Open Access Journals at Digital Commons @ University of South Florida. It has been accepted for inclusion in Genocide Studies and Prevention: An International Journal by an authorized editor of Digital Commons @ University of South Florida. For more information, please contact digitalcommons@usf.edu. 


\title{
Case Study: The International Criminal Tribunal for the Former Yugoslavia's Court Transcripts in Bosnian/Croatian/Serbian
}

Part 1: Needs, Feasibility, and Output Assessment

\author{
Besmir Fidahić \\ Maastricht University \\ Maastricht, The Netherlands
}

\section{Introduction $^{1}$}

The ICTY was an independent institution which functioned in accordance with its Statute (ICTY-S) $)^{2}$ and its Rules of Procedure and Evidence (RPE) ${ }^{3}$ - these have been amended 9 and 52 times respectively since 1993 when they were originally delivered. Most critics stop short from calling them cut-and-pasted versions of the International Military Tribunal's Charter. ${ }^{4}$ Defenders seem to concede the ICTY-S was "drafted quickly," but highlight the large number of revisions to the ICTY RPE, reflecting one of the main advantages of having judges do the rulewriting: the ability to quickly take into account lessons learned from concrete experiences in the courtroom. ${ }^{5}$ Indeed, both ICTY RPE Rule 6 and the self-explanatory Procedure for the Proposal, Consideration of and Publication of Amendments to the [RPE] of the [ICTY] (1998, r. 2001 and 2002), stipulate that the Rules Committee shall consider all proposals for amendment of the Rules forwarded to it by the President, a Judge of the International Tribunal or other body. ${ }^{6}$

Pursuant to the ICTY-S, Article 11, the ICTY consists of the Chambers, comprising three Trial Chambers and an Appeals Chamber; the Prosecutor; and a Registry, servicing both the Chambers and the Prosecutor. As Defense was not a part of the ICTY, they were taken care of by the ICTY Registrar through the Division of Judicial Support Services. ${ }^{7}$ The ICTY Registry was also in charge of the overall administration of the Court, including the provision of language services through the Conference and Language Services Section (CLSS). In general, the provision of language services in the $\mathrm{UN}$ is done according to the policies of multilingualism where two of six official UN languages (Arabic, Chinese-Mandarin, English, French, Russian, Spanish) are proclaimed official languages in each UN organization and entity where they are used "in fairness and parity" in internal and external communication. ${ }^{8}$ There is no "One UN, one language policy" in the UN which means the CLSS could not influence or change the overall UN language policy. However, they had legal obligation and legal facets to adapt and inform the ICTY language policies as per ICTY RPE Rule 6 and the Procedure for the Proposal, Consideration of and Publication of Amendments to the [RPE] of the [ICTY]. This case-study is going to examine whether the CLSS did that by examining their legal obligation to provide the

\footnotetext{
1 The views expressed in this Case Study belong solely to the author. Due to their technical nature, Case Studies do not undergo the double-blind peer review process.

2 ICTY, Updated Statute of the International Criminal Tribunal for the Former Yugoslavia, September 2009.

${ }^{3}$ ICTY, Rules of Procedure and Evidence, July 8, 2015 (IT/32/Rev.50).

${ }^{4}$ Gregory S. Gordon, Atrocity Speech Law: Foundation, Fragmentation, Fruition (Oxford: Oxford University Press, 2017).

5 Theodor Meron, The Making of International Criminal Justice: The View from the Bench: Selected Speeches (Oxford: Oxford University Press, 2011).

${ }^{6}$ ICTY, Practice Direction on Procedure for the Proposal, Consideration of and Publication of Amendments to the Rules of Procedure and Evidence of the International Tribunal (as amended), January 24, 2002, (IT/143/Rev.2).

7 "Organization of the ICTY," ICTY, accessed July 7, 2021, https://www.icty.org/en/about/tribunal/organisationalchart.

8 Papa Louis Fall and Yishan Zhang, Multilingualism in the UN System Organizations: Status of Implementation (Geneva: United Nations, Joint Inspection Unit, 2011), (JIU/REP/2011/4), accessed September 21, 2021, https:/ / undocs.org/ en/JIU/REP/2011/4.
}

Besmir Fidahić. "Case Study: The International Criminal Tribunal for the Former Yugoslavia's Court Transcripts in Bosnian/Croatian/Serbian." Genocide Studies and Prevention 15, no. 2, 37-48. https://doi.org/ 10.5038/1911-9933.15.2.1846.

(C) 2021 Genocide Studies and Prevention. 
essential part of any permanent court record, the court transcripts. Was there a need for ICTY court transcripts in the Bosnian/Croatian/Serbian (B/C/S) languages? Could the ICTY court transcripts have been made in the $\mathrm{B} / \mathrm{C} / \mathrm{S}$ from the very beginning of the institution and whether the existing ICTY court transcripts in the B/C/S are up to par for any of its audiences?

Should one wish to discuss the ICTY language policies and its effect on ICTY legacy and struggle against denialism, as this paper does, one should start by inspecting the ICTY data. This gives a validity to a reason why this case-study is not heavy on traditional academic literature review. Methodology followed respected the principles of qualitative research where a problem was discussed from the perspectives of recipients and subjects of ICTY language services and policies: the situation country (posterity), the parties to the proceedings (B/C/S speaking defense and victims and witnesses), and the local judiciary (next users and elaborators of ICTY legal reasoning). These B / C/S speaking clients need(ed) the ICTY B/C/S transcripts to engage in their own legal work, to see and to hear the atrocities of wars fought in the territory of the former Yugoslavia in their alleged name, and to gain insight into the criminal behavior of individuals and groups in order to start eliminating the causes that led to the situation in the first place, to start gaining critical perspectives on the issues, and to start neutralizing all causes perpetuating the situation in the present. Otherwise, the ICTY's mission in the former Yugoslavia cannot be said to be complete. In the first part of this study, the author will provide brief history of ICTY language policies affecting court transcripts and its effects on the above three groups of recipients of ICTY B/C/S transcripts. Then, the author will provide background to the court reporting services at ICTY. Finally, the author will provide extended summary of main findings on the existing transcripts in the $\mathrm{B} / \mathrm{C} / \mathrm{S}$ stemming from his original research published elsewhere in full.

This discussion is primarily informed by the author's original research published elsewhere in fuller detail, including the ICTY-S, ICTY RPE, ICTY Annual Reports (AR), ${ }^{9}$ the ICTY Defense Manual (Defense Manual), ${ }^{10}$ the ICTY Manual on Developed Practices (ICTY Manual), ${ }^{11}$ other ICTY documents, including videos, as found on the ICTY official website. The reason why the ICTY website was chosen as a source of information for this study is because the background paper on the assessment of the legacy of ICTY proudly exclaims the ICTY's website is the primary tool for providing wide access to the ICTY's cases and records. The website was comprehensively overhauled in 2008, and several new features were introduced, including complete multilingualism in English, French and B/C/S (plus selected materials in Albanian and Macedonian), as well as a fresh look and a clear structure. ${ }^{12}$ It is hoped that these three groups of sources will provide a balanced holistic background to this paper.

\section{UN and ICTY Language Policies Affecting Court Transcripts}

The provision of language services in the UN is done by the UN Department for General Assembly and Conference Management (DGACM). However, UN DGACM language professionals service only some principal organs of the UN set up at the UN Charter-the General Assembly, Security Council, Economic and Social Council, and the Secretariat-in offices in Addis Ababa, Bangkok, Beirut, Geneva, Nairobi, New York, Santiago, and Vienna, and only in the six official languages of the UN, namely Arabic, Chinese, English, French, Russian, and Spanish. As stated in the Introduction, the provision of language services in the UN is done

\footnotetext{
9 “Annual Reports," ICTY, accessed July 7, 2021, https://www.icty.org/en/documents/annual-reports.

${ }^{10}$ United Nations Interregional Crime and Justice Research Institute (UNICRI), Manual on International Criminal Defence: ADC-ICTY Developed Practices Documents: Within the Framework of the War Crimes Justice Project (The Hague: UNICRI Publisher, 2011), accessed July 7, 2021, https://www.icty.org/x/file/About/Reports\%20and\%20Publications/ manual developed practices/ADC ICTY developed practices en.pdf.

11 UNICRI, ICTY Manual on Developed Practices (The Hague: UNICRI Publisher, 2009), accessed 21 September 2021, https://www.icty.org/x/file/About/Reports\%20and\%20Publications/manual developed practices/ icty manual on developed practices.pdf.

12 ICTY, Assessing the Legacy of ICTY: The Background Paper (The Hague: ICTY, 2010), accessed July 7, 2021, https:// www.icty.org/sid/10292.
} 
according to the policies of multilingualism where two of six official UN languages are proclaimed official languages in each UN organization and entity where they are used "in fairness and parity" in internal and external communication. ${ }^{13}$

The UN DGACM does not provide language services to many other UN entities; these establish their own language services. Although the ICTY has always fallen under the Subsidiary Organs of the Security Council, which is serviced by the UN DGACM, there is very little evidence the UN DGACM even acknowledged the ICTY language services. As to the ICTY management, they complied with the UN policies of multilingualism. ${ }^{14}$ As an institution, the ICTY-S does not set the official languages of the ICTY-although mentioned twice in the ICTY RPE Rules 47(G) and 55(C), "official languages" have nowhere been clearly set. The ICTY-S, Article 33 and the ICTY RPE Rule 3(A) explicitly set English and French as the working languages. The ICTY RPE Rule 3(C) combines "other persons appearing before the Tribunal, other than as counsel" giving those persons the right to use their own language. ${ }^{15}$ The languages of the former Yugoslavia-Bosnian, Croatian, and Serbian, collectively known as the $\mathrm{B} / \mathrm{C} / \mathrm{S}$ at the ICTY, and formerly known as the Serbo-Croatian-do not figure among the official languages of the UN and cannot be accommodated by the UN DGACM. The lawmakers set two UN languages as the official languages of the ICTY and completely ignored the language of the situation country, here B/C/S, the raison d'être of the ICTY and the language of ICTY's main clients: B/C/S speaking accused, victims, witnesses, defense counsels, and the region of the former Yugoslavia. This set the delivery of language services at the ICTY to failure right from the outset.

As per ICTY RPE 66(A)(i) and (ii) the CLSS had a legal obligation to deliver specific documents including, inter alia, copies of all transcripts and written statements taken in accordance with Rule 92 bis (on admission of written statements and transcripts in lieu of oral testimony), Rule 92 ter (on admission of other written statements and transcripts), and Rule 92 quarter (on unavailable persons). In practice, looking for a loophole in the existing language laws and trying to make as much trouble as possible for everyone, Šešelj started his war on ICTY language services requesting court transcripts in Serbian and the Cyrillic script; the protracted ordeal resulted in an international fiasco with dire consequences for the insider witnesses against Šešelj whose identities have been publicly revealed while they were still in Serbia squirming with Šešelj's supporters. ${ }^{16}$ Similar attempts by defendants and their defense counsels requesting transcripts in the $\mathrm{B} / \mathrm{C} / \mathrm{S}$ and in the Cyrillic script were stopped at the outset. ${ }^{17}$ However, they were not stopped due to the practical language-related problems. The judges took charge and designed the standard practice at the ICTY to suit the Court: defendants were allowed translation of basic documents (ICTY RPE Rules 66(A), 66(A)(i), 66(A)(ii) and

\footnotetext{
${ }^{13}$ Fall and Zhang, Multilingualism in the UN System Organizations. First mentioned in footnote 7.

${ }^{14}$ For example, ICTY President Claude Jorda (1999-2003) remarked the following: "I can only regret that French, as an official language of the [UN] and a working language of the Tribunal, is under-represented, in particular with regard to internal communications." The parity in use of English and French never worked out in practice; I have written about its effects on multilingual delivery of court documents elsewhere in much more detail. See United Nations, Seventh Annual Report of the Internal Tribunal for the Prosecution of Persons Responsible for Serious Violations of International Humanitarian Law Committed in the Territory of the Former Yugoslavia since 1991, August 7, 2000 (A/ 55/273-S/2000/777).

${ }^{15}$ Here, we can see Judge Güney complying with the UN policies on multilingualism by speaking English in Tolimir and by speaking French in Lukić. Other ICTY judges could be seen communicating both in English and French, as well, at least during procedural prewritten matters. It would be fair to say that the only ones who did not were the native speakers of English and/or French. See ICTY, "Appeals Judgement, Tolimir: 08 April 2015," YouTube video, 01:12:37, uploaded April 8, 2015, accessed July 2, 2021, https://youtu.be/HE8xMksBd1w; ICTY, "Arrêt, Milan Lukić \& Sredoje Lukić: 4 Décembre 2012," uploaded April 8, 2015, accessed July 2, 2021, https://youtu.be/ mM25Twga93U.

16 "Court Transcript in Šešelj," ICTY, March 25, 2003, accessed July 2, 2021, https:/ / www.icty.org/x/cases/seselj/trans/ en/030325IA.htm, T. 57-59, 76, 98-99.

17 "Court Transcript in Tolimir," ICTY, September 14, 2007, accessed July 2, 2021, https://www.icty.org/x/cases/ tolimir/trans/en/070914SC.htm, T. 62-70.
} 
transcripts pursuant to ICTY RPE Rule 66) to be delivered to them in B/C/S and in the Latin script. Those transcripts that were not made in the $\mathrm{B} / \mathrm{C} / \mathrm{S}$ were given to defendants and defense in an audio or video form. ${ }^{18}$ Various time limits to respond to various court decisions specified elsewhere remained the same. But, was there an actual need for ICTY B/C/S transcripts beyond the abuse of the system privileges and stalling the process?

The ICTY Manual acknowledges the accused do not have transcripts of proceedings readily available in the $\mathrm{B} / \mathrm{C} / \mathrm{S}$ and must use audio/visual tapes. It also acknowledges time delays-cases can sometimes involve hundreds of witnesses and the lack of transcripts had the potential to create delays and inefficiencies in the use of courtroom time. The ICTY tried offsetting the problem by introducing an electronic transcript management application for the recording, storage, and use of witness testimony transcripts throughout trial and appellate proceedings. ${ }^{19}$

The ICTY Manual also acknowledged the lawyers from the former Yugoslavia-nonEnglish or non-French speaking lawyers who wanted to consult transcripts were also given access to the audio/visual material in the $\mathrm{B} / \mathrm{C} / \mathrm{S}$ language. This process is both cumbersome and costly to the referral state because they must then listen to the audio/visual record, and then transcribe the testimony in their own language. ${ }^{20}$

Finally, admitting the accurate transcripts of proceedings are critical, ICTY Manual advises court reporting should not be placed under CLSS, but under court management services. In ICTY Manual's view, transcripts involve verbatim reporting of what was said in the courtroom and do not require translation or interpretation skills. At the ICTY, court management sets the requirements for court reporting, and receives and controls the transcript. CLSS's role as court reporting project manager is therefore limited to the contractual and financial aspects only. The overall task is not within the domain of a language service. ${ }^{21}$

It is curious that the ICTY Manual and the Defense Manual did not make a single statement on how unavailability of B/C/S transcripts affected defense. The Defense Manual glosses over the issue of actual transcript-making, concentrating mostly on their admissibility and mentions the practical problems created by non-existence of $\mathrm{B} / \mathrm{C} / \mathrm{S}$ transcripts only once. In the context of the Law on Transfer of Cases from the ICTY to the Prosecutor's Office of Bosnia \& Hezergovina $(\mathrm{B} \& \mathrm{H})$ and the use of evidence collected by ICTY in proceedings before the courts in $\mathrm{B} \& \mathrm{H},{ }^{22}$ advising defense counsel can use ICTY transcripts to identify inconsistencies in the witnesses' accounts and thus, prepare for effective cross-examination. ${ }^{23}$ Author's informal conversations with ICTY Defense support staff, a hybrid professionals combining the roles of case manager, translator, interpreter, researcher, and legal assistant in one person revealed that in addition to routinely comparing the B/C/S audio with the English/French transcripts of court sessions, these professionals were also given duties to listen to the in-court interpretation into $\mathrm{B} / \mathrm{C} / \mathrm{S}$ and alert lead defense attorneys to critical problems with interpretation.

The Defense Manual acknowledged one of the major barriers to regional information sharing is linguistic in nature. ${ }^{24}$ This was acknowledged by B\&H and Croatia's prosecutors during the conference on the ICTY legacy held in Sarajevo and Zagreb in 2012. The parties complained that even when they receive ICTY B/C/S transcripts, these do not include closed

\footnotetext{
18 Prosecutor v. Karadžić, Decision on the Accused's Request that all Materials, including Transcripts, be Disclosed to him in Serbian and Cyrillic script, September 25, 2008, IT-95-5/18-PT.

19 UNICRI, ICTY Manual on Developed Practices, 96. First mentioned in footnote 10.

20 Ibid., 174.

${ }^{21}$ Ibid., 187.

${ }^{22}$ Law on Transfer of Cases from the ICTY to the Prosecutor's Office of B\&H and the use of Evidence Collected by ICTY in Proceedings before the Courts in $\mathrm{BiH}$, Official Gazette of Bosnia and Herzegovina No. 61/04, 46/06, 53/06, $76 / 06$

${ }^{23}$ UNICRI, Manual on International Criminal Defence, 225. First mentioned in footnote 9.

24 Ibid., 227.
} 
sessions where the witnesses may have made certain identification of people, documents, and locations critically relevant for work of the local judiciary. ${ }^{25}$

\section{ICTY Court Transcripts}

The ICTY was make-shifting as far as the B/C/S transcripts are concerned. Efforts at improving the transcript system are commendable and they must have made lives of English and French speaking staff much easier. But it is unclear how any helped if a B/C/S speaking witness testified several times- $\mathrm{s} /$ he would still have to sit and listen to their testimony off audio or video materials in the $\mathrm{B} / \mathrm{C} / \mathrm{S}$ which took away their time and took away money from the ICTY having to entertain a witness for days. Furthermore, it is unclear how it helped with expeditious trials against $\mathrm{B} / \mathrm{C} / \mathrm{S}$ speaking defendants or the $\mathrm{B} / \mathrm{C} / \mathrm{S}$ speaking overall audiences then and now; it is much easier to read a transcript in $B / C / S$ than to soldier through an audio or video recording of $\mathrm{a}$, by definition, agitated and overly excited legal client and complex legal reasoning. As far as Defense is concerned, their jobs, at least, would have been much easier if there were $\mathrm{B} / \mathrm{C} / \mathrm{S}$ transcripts. Instead, given that Defense was bound by very strict deadlines, the lack of $\mathrm{B} / \mathrm{C} / \mathrm{S}$ transcripts put undue pressure on them. As for the legacy, even when the local judiciary in the former Yugoslavia gained B/C/S transcripts, critical parts crucial for their work were still missing. The overwhelming need for full transcripts is obvious. Could the ICTY $\mathrm{B} / \mathrm{C} / \mathrm{S}$ transcripts be made from the onset?

The provision of language services at ICTY was largely uninformed and highly segmented. On the one hand, there was the official language services provider, CLSS, but on the other, it seems every other unit had their own language services: Rules of the Road (extended summaries of case files submitted for review of jurisdiction between the ICTY and local judiciary), UN Detention Unit (translation and consecutive interpreting for detainees), the ICTY Victims and Witnesses Unit (getting the victims and witnesses to The Hague from their areas of residence), the ICTY court reporters (court transcripts), the Outreach Program (news and publications in the languages of the former Yugoslavia), the Chamber Support Unit (legal drafting), and the Office of the Prosecutor (OTP) (translation of evidence and interpreting for clients, etc.) all had their informal, semi-formal, or formal language units. These seven language-related units that were completely separate from the CLSS and completely dependent on donations as detailed in all ICTY ARs were serviced by the so-called Language Assistants; the author has written about Language Assistants elsewhere. ${ }^{26}$

Arrangements behind the use of court reporters were a part of this larger problem with the CLSS's inability to self-regulate. The court reporters belong to a category of officers of the court in certain legal traditions or, rather, they are an integral part of courts. However, when the ICTY was established, similarly to other international criminal tribunals, court reporters were unknown in the UN System. The UN recognizes the category of verbatim reporters, instead. These are regularly used at standing UN courts (International Court of Justice, UN Dispute Tribunal, and Administrative Tribunal of the International Labor Organization) and the UN Secretariat. The difference between the ICTY, and other court reporters and verbatim reporters in the UN System is that court reporters produce verbatim transcript of court sessions, whereas "[c]ombining the skills of transcription, translation and editing, verbatim reporters ensure the substantive accuracy of all statements, while maintaining a uniformly high standard of style." 27 In other words, the end product of verbatim reporters' work is not a verbatim transcript, but an extended summary of facts, and they do not use any specialized equipment in the performance of their jobs. Naturally, this does not work for a court where every word

\footnotetext{
${ }^{25}$ Nerma Jelačić, Legacy of the ICTY in the Former Yugoslavia (The Hague: ICTY Outreach Programme, 2013), 61.

${ }^{26}$ Besmir Fidahić, Linguistic Justice at the International Criminal Tribunal for the Former Yugoslavia (Newcastle upon Tyne: Cambridge Scholars Publishing, 2021).

${ }^{27}$ United Nations Careers, "Verbatim Reporters," United Nations, accessed July 7, 2021, https://careers.un.org/lbw/ home.aspx?viewtype $=$ LCEFD\&FId $=4$.
} 
uttered needs to be transcribed verbatim and kept as a part of the court record. It follows that the ICTY could not have used existing UN resources as court reporters.

The evolution of court reporting services at the ICTY can be easily followed through ICTY ARs. The ICTY acknowledged from the very beginning that they could not move forward without language professionals, but were struggling with basic terminology-they described them as "specialized stenotypists," not as "court reporters" as they are professionally known throughout the industry. 28 This is not nitpicking, but a rather straightforward indication of legal professionals' awareness of language-related work. The ICTY ARs also stated that CLSS was responsible for hiring English and French court reporters who have a duty to prepare transcripts of all sessions in court. ${ }^{29}$ Here, again, it is unclear why the charge to hire and supervise court reporters was given to CLSS as, in most jurisdictions, court reporters are hired and supervised directly by the courts. ICTY ARs also state that the work in the courtroom requires the permanent services of court reporters for the ICTY's two working languages: English and French. ${ }^{30}$ The CLSS understood "permanent services of court reporters" not as those stemming from the use of in-house sources as the word "permanent" used in employment context normally suggests, but rather "permanently outsourced." So, the CLSS hired court reporters from outside companies from the very beginning. The ICTY Procurement Office would make an Invitation to Tender and select the agency that outsources court reporters on the basis of their passing the court reporter test and, naturally, their price. The ICTY staff report that a single agency always won these tenders from the start.

As to the English language court reporters, in-house contractors of the outsourced company, they work in a team of two: one sitting in the actual courtroom and the other one sitting in a nearby office, revising work of an in-courtroom colleague (names, locations, misspellings, etc.). French language court reporters work(ed) off-site. Since they were located in Canada (-6 CET), they were able to respond to deadline to submit camera-ready transcripts ending at two hours after the court ends the session. Although the author of this study was not in any way privy to information contained in the contract between ICTY and the agency that outsourced court reporters, two things are certain: hiring through an agency is much more expensive than hiring directly, and since the ICTY investigative and prosecutorial workload only kept growing and court reporters are recognized professionals who are readily available in the global market both for English and French, the ICTY ought to have hired a few court reporters as in-house staff. However, CLSS did not do any such thing.

As to the ICTY court reporters' substantive tasks, it was clear from the very beginning of their engagement at the ICTY that they were primarily to cater to the Court by creating English and French court transcripts. However, practice has shown a certain curiosity to their engagement which seems to have much to do with the type of contract they signed with CLSS. In the beginning, court reporters were paid by page and then by court session. Obviously, if they were hired on a different type of contract or as in-house staff, the page and hour restriction would not figure in the equation. Such court reporters could have been used to shorten the tediously lengthy process of manual transcription of video and audio recordings which are ubiquitous in any investigation or prosecution office, including the ICTY. Instead, English and French court reporters have always been used for the needs of the Court alone and have rarely been used by the OTP or Defense for their transcription needs. ${ }^{31}$ The OTP and the Defense could

\footnotetext{
28 United Nations, Report of the Internal Tribunal for the Prosecution of Persons Responsible for Serious Violations of International Humanitarian Law Committed in the Territory of the Former Yugoslavia since 1991, August 23, 1995 (A/ 50/365-S/1995/728), para. 90.

29 UN, Report of the Internal Tribunal for the Prosecution of Persons Responsible for Serious Violations of International Humanitarian Law Committed in the Territory of the Former Yugoslavia since 1991, August 16, 1996 (A/51/292-S/ 1996/665), para. 134.

$30 \mathrm{UN}$, Report of the Internal Tribunal for the Prosecution of Persons Responsible for Serious Violations of International Humanitarian Law Committed in the Territory of the Former Yugoslavia since 1991, September 18, 1997 (A/52/375-S/ 1997/729), 109.

${ }^{31}$ ICTY OTP Srebrenica team, for example, claims they received a lot of assistance from the ICTY court reporters.
} 
have used court reporting services almost every day, given numerous interviews with clients conducted in English or French. Also, given that the witness statements were written down in English instead of being taped, the court reporters could have been used to transcribe those, as well, thus contributing significantly to the way witness statements were taken. But, since the contract court reporters signed with CLSS precluded them from being used for any of these purposes, French and/or English, and/or B/C/S, and/or Macedonian, and/or Albanian, Defense and OTP client interview transcripts then had to be made by their respective Language Assistants.

All this had a bearing on transcripts: if it was hiring outside court reporters, de facto strangers to the UN completely unregulated by any codes of conduct in the existing UN administrative laws, the ICTY should have hired in-house "transcript checkers" to ensure accuracy and completeness of outsourced transcripts. Since there was no Interpretation Monitor, an entity regularly used at Nuremberg to monitor the in-court communication and fix problems with interpretation then and there, ${ }^{32}$ these "transcript checkers" could have also checked the quality of in-court interpreting. ${ }^{33}$

Post-2000 ICTY ARs report that CLSS explored the possibility of finding a more costeffective method of producing transcripts through off-site reporting. ${ }^{34}$ The CLSS Deputy Chief went to the ICTR in order to, inter alia, exchange views on the interpreting and court reporting systems several times. ${ }^{35}$ Notwithstanding, it is, again, worth remembering that the agency that won the first tender for court reporters in 1994 remained unchanged. It is unclear why it did not occur to the ICTY or ICTR management to hire in-house court reporters, transcript checkers as a check and balance to court reporters' work, or an Interpretation Monitor; if any corrigenda to English and French transcripts were made, it was requested by the parties to the proceedings. ${ }^{36}$

Could ICTY transcripts have been made in B/C/S from the very beginning? Here, this study will first turn to equipment used to transcribe the court proceedings because it is crucial for the use of languages. There were two options for making transcripts in B/C/S: classical

32 See Francesca Gaiba, The Origins of Simultaneous Interpreting: The Nuremberg Trial (Ottawa: University of Ottawa Press, 1998).

33 In 2016, ECCC announced a series of vacancies for Language Reviewers in combination French to English (United Nations Assistance to the Khmer Rouge Trials, Consultant Language Reviewer-French to English, Tuesday, March 22, 2016, VA/TU/2016/02) and Khmer to English (United Nations Assistance to the Khmer Rouge Trials, Consultant Language Reviewer-Khmer to English, Tuesday, July 12, 2016, VA/TU/2016/07) with a duty to review transcripts of trial proceedings in the target language against the digital audio recordings in the source language, edit and translate, when necessary, the transcripts to correct substantive errors or omissions detected in the interpreting using the audio recordings in the source language, edit the transcripts to ensure accuracy and consistency in terminology, spelling, grammar and punctuation following the Transcript Unit's guidelines and glossaries, and finalize the transcripts prior to distribution to relevant parties.

${ }^{34} \mathrm{UN}$, Report of the ICTY, 2000 (A/55/273), para. 244. First mentioned in footnote 13.

35 Ibid., 203.

36 The UN might have had something against employing court reporters because UN hires staff with university level education on the so-called P-level (professional) positions. Therefore, the lack of university diploma could be one impediment to recruitment of court reporters in the UN on P-level positions. To that effect, it is plausible to assume that English and French associations gathering court reporters would not take kindly to their court reporters being employed on GS-level (general support) positions because they are, after all, equipped with special skills and knowledge to perform these duties. The ICC was established in 2002. However, it is assumed that they also outsourced their court reporters until they started advertising for P-2 in-house court reporters specifically stating that, as far as education is concerned, candidate must have "post-secondary specialised training in court reporting, followed by intensive training in the profession" and "certification as a court reporter by passing a registered professional reporters' examination is essential" without any mention of an actual university diploma. See ICC's vacancy announcement for example, "International Criminal Court (ICC), Court Reporter-English, The Hague, 2013, Vacancy Announcement No: 3031EE-RE," Jobs in Zambia (blog), accessed September 21, 2021, http:// zambiajobs.blogspot.com/2013/11/court-reporter-english-hague.html. Although it remains unclear why it took the ICC 11 years to start hiring court reporters as full-time staff, two things seem likely. The first thing is that ICC is starting to explore a cheaper option to court reporters' engagement, and the second, ICC is doing these court reporters a favor by hiring them on P-level posts because they are not in possession of required university education. 
stenography notetaking followed by transcribing, and computer stenography on the stenotype machine and a computer program for simultaneously recording and transcribing speech. This stenotype machine is regularly used by court reporters in Common Law countries, including at the ICTY. Unfortunately, so far, none of those stenotype machines were adapted for use in B/C/ $\mathrm{S}$ languages, despite all the best efforts of the local practitioners in the former Yugoslavia. Could the court reporters using the stenotype machine and related computer software be used to make $\mathrm{B} / \mathrm{C} / \mathrm{S}$ transcripts? The answer is: no, such machines and such practitioners do not exist for any of the $\mathrm{B} / \mathrm{C} / \mathrm{S}$ languages.

Now, could the manual stenographers be used to record proceedings in the B/C/S? The manual stenographers were working as court reporters throughout the First and the Second Yugoslavia; Yugoslavian Association of Stenographers and Dactylographers was functional between 1945 and 1990, bringing together all professional associations from all the republics, but the collapse of Yugoslavia led to the demise of this Association. ${ }^{37}$ As we saw before, the ICTY as in whole made full and heavy use of Language Assistants, and CLSS was promoting their services, as well. Could the manual stenographers be used to record proceedings in B/C/S from the very beginning of the ICTY (1993)? Yes, they could. Could manual stenographers be used to record proceedings in B/C/S right now (2021)? Yes, they could. However, none of them were used to transcribe ICTY court proceedings in B/C/S then and they are still not used now.

\section{Efforts to Make Transcripts in the B/C/S}

There was no internal or external impediment to using ICTY internal resources, such as Language Assistants, or manual stenographers to record the proceedings in the $\mathrm{B} / \mathrm{C} / \mathrm{S}$ from the very beginning of ICTY. Was any of it done and what were the results?

In 2008, a team of experts, led by the OSCE's Office for Democratic Institutions and Human Rights, in conjunction with the ICTY and the UN Interregional Crime and Justice Research Institute, carried out a needs assessment among the judiciaries in the former Yugoslavia in order to transfer the wealth of knowledge from the ICTY and build the capacity of local judiciaries before the ICTY completes its mandate. In 2009, these findings were published in a report entitled, "Final Report: Supporting the Transition Process: Lessons Learned and Best Practices in Knowledge Transfer." One of the key findings in relation to the needs of local judiciaries in order to efficiently process the war crimes on the local level was a lack of ICTY court transcripts available in local languages. The three organizations jointly started an 18month long "War Crimes Justice Project" in order to address those needs.

In July 2010, the ICTY Registry recruited a team who began creating verbatim transcripts of ICTY court proceedings in B/C/S from B/C/S audio recordings of ICTY court proceedings. It was reported the ICTY engaged a team of 20 transcribers-ICTY Language Assistants who accepted the job because they were going to be made redundant soon. The team transcribed a total of over 60,000 pages in $\mathrm{B} / \mathrm{C} / \mathrm{S}$ in those 18 months. The transcription project mainly addressed the most pressing needs of the local judiciaries in terms of assisting their ongoing trials and investigations within the available funding, time, and resource restraints. Unfortunately, on the project's completion in December 2011, the transcription project was discontinued due to a lack of additional funding. Currently, it is not clear whether the project would be continued. 38

These ICTY Registry transcripts were made only in B/C/S, not in Albanian or Macedonian, the languages of some defendants and some audiences in the situation country. The B / C/S transcripts of some, though not all, court sessions were made in trials: Blagojević and Jokić (12/145 trial days), Brđanin (7/284), Erdemović (2/n/a), Halilović (4/77), Karadžić (11/499),

\footnotetext{
${ }^{37}$ Author's most profound thanks go to Mr. Josip Hanjš, President of the Croatian Shorthand Association, for his help with the history and the future of stenography in the former Yugoslavia.

38 Organization for Security and Co-operation in Europe (OSCE), Supporting the Transition Process: Lessons Learned and Best Practices in Knowledge Transfer: Final Report. Warsaw: September 2009. Accessed September 21, 2021. https:// www.icty.org/x/file/About/Reports\%20and\%20Publications/report supporting transition en.pdf.
} 
Krajišnik (164/314), Krstić (3/98), Lukić (10/85), Nikolić (1/n/a), Popović (222/425), Stanišić and Župljanin (116/354), Tolimir (3/242), and Vasiljević (1/54) (B\&H as a situation country), Martić $(156 / 148)$ (Croatia as a situation country), Đorđević (5/199) and Šainović (3/285) (Kosovo as a situation country), and Perišić (4/198) and Milošević (42/n/a) (the influence of the Serbian political and military leadership over Serb rebels and Serb(ian) insurgents in B\&H, Croatia and Kosovo). 39

This shows the ICTY Registry B/C/S transcript team produced a total of 766 court days of transcripts of more than 10,800 court days overall. The reports boasted that the ICTY Registry $\mathrm{B} / \mathrm{C} / \mathrm{S}$ transcript team had reached a goal of producing 60,000 pages of transcript out of 2,5 million pages of transcripts overall.

Such production indicators given in pages of transcript are not helpful at all for any assessment of the successfulness of the project. Transcribers' production is measured in minutes of recorded material, not in the number of pages produced. In other words: how many minutes of recorded material they transcribed, not how many pages they can produce. This is because the number of words appearing on a page is unpredictable: one single page may have a series of "uh-huhs" or it may have full text from top to bottom, in addition to transcribing tags identifying speakers and the proceedings. Given all the constraints with the actual recording, the transcription industry accepted minimum is four hours of transcription time for one hour of clear audio, or a 4:1 ratio. In other words, 15 minutes of audio per one hour of work or 120 minutes of transcribed audio material in an 8-hour working day. 40

The other problem with the reported 60,000 pages is that some pages are heavily redacted with only a sentence on them. Author's Excel spreadsheet counted all the Evidence registration number (ERN) ranges of transcribed material and came up to a total of 62,610 pages. Next, after the author recorded the number of pages in each court session as given by the PDF Viewer to which they were posted, added 1 to account for the actual number of pages, the Excel spreadsheet counted them all and came up with 59,903 actual pages. This means the ICTY Registry B/C/S transcript team managers did not report properly to the donors that they produced 60,000 pages of transcript because they were short 97 pages of achieving that goal.

As to the number of pages that had been actually transcribed, there were several constraints calculating them. English and French transcript templates have 25 lines per page; the ICTY Registry B/C/S transcript team template had 30. The shortest transcript found was 3 pages long (March 6, 2006, Martić) and the longest was 151 pages long (June 23, 2005, Krajišnik) which, following subtractions and divisions, could be taken to mean that the average transcript was about 74 pages long.

According to the calculations from above, the 30-line, 74-page transcript should have 2,220 lines, but the author found that the B/C/S transcript one had just 1,420 lines, which means a 74-page transcript, taken as an average length transcript, has a shortfall of about $35 \%$ as it is.

Then, the author recorded and duly counted every single full blank page and full ERN range inserted to consolidate between the English and the French transcripts which brought the grand total of actually transcribed pages of the ICTY Registry B/C/S transcripts from 59,903 down to 58,954 .

Finally, since a total number of the ICTY Registry B/C/S transcripts contained a certain number of blank pages of redacted material, the author recorded and duly counted every single

\footnotetext{
39 The data on total trial days in the above cases was taken as recorded in the Case Information Sheet; the author counted the days transcribed as they appear in the B/C/S transcripts. The value $\mathrm{n} /$ a means that there were no trials in this case because the defendant pleaded guilty or that he died before the trial was over. The discrepancy in the total days of trial and the days in the B/C/S transcripts in Martić might be because there is an error in Martić Case Information Sheet: 156 days in the B/C/S transcripts correspond to 156 days found in the English language transcript; this case seems to be the only trial that has been transcribed in full.

40 Chloe Brittain, “Transcription Time Per Audio Hour: How Long Should Transcribing Actually Make?," Opal Transcription Services, n.d., accessed September 21, 2021, https://www.opaltranscriptionservices.com/ transcription-time-per-audio-hour/.
} 
full blank page and full ERN range of redacted material in the ICTY Registry B / C S transcripts, counting only clearly marked full redacted pages which brought the grand total of actually transcribed pages of ICTY Registry B/C/S transcripts from 58,954 down to 55,916.41

This established the internal ICTY and OSCE reports, including the donor reports citing the number of pages transcribed by the ICTY Registry B/C/S transcript team as "more than $60,000, " 42$ should now correct their information to "a little bit above 55,000;" or even "a little less than 56,000."

Since the number of pages of transcribed material is not at all a production indicator, the author recorded the times of court sessions, the Excel duly performed times calculations whereupon it was established that the ICTY Registry B/C/S transcription team transcribed a total of 2,657 hours and 41 minutes of audio material during the 18-month life of this project.

Considering the number of staff in the ICTY Registry B/C/S transcription team, the time at their disposal, and the audio quality of court sessions, this number seems subpar.

Although the minimum transcription industry standard is 15 minutes of transcribed material an hour, the author decided to calculate the daily output based on a 7-hour working day which brought the author to a minimum of 105 minutes of transcribed material a day, instead of 120 minutes.

A UN month has 21 days, the UN allows 45 days of annual leave, 15 days of uncertified sick leave, and 15 days of official holidays in 18 months; the latter must be taken. These criteria allow for the following combinations and calculations:

$$
20 \times(105 \times((18 \times 21)-x))
$$

* Substitute $x$ for either $75,60,30$, or 15 to indicate the number of days off.

It would thus take, to transcribe, an absolute minimum output of 10,605 hours (-75 days off), an upper median output of 11,130 hours (-60 days off), a lower median output of 12,180 hours (-30 days off), or an absolute maximum output of 12,705 hours (-15 days off).

Obviously, with an end result of only 2,657 hours of transcribed material, the ICTY Registry B/C/S transcription team did not reach the bare minimum of 10,605 hours, lower medium of 11,130 hours, upper medium of 12,180 hours or absolute maximum of 12,705 hours of transcription output according to the transcription industry standards even with author's overly liberal calculations of a 7-hour workday and the bare industry minimum of 15 minutes per hour indicating a shortfall of around $75 \%$.

In 2018, the "Om3ga Solutions" developed an application called "Daktilograf" (typist or dactylographer). This application converts speech originally delivered in B/C/S to text with an accuracy of more than $95 \%$ in the real-time operation. The company already has a wide clientele using this application ranging from various industries to institutions of public administration in the former Yugoslavia. As the human work on the B / C/S transcripts would amount to revising, this application promises results in a rather short period of time, as well. 43 Could this application be used to complete pending work on B/C/S transcripts? The answer is: yes, it could.

\section{Conclusion}

The ICTY transcripts could have been made in the $\mathrm{B} / \mathrm{C} / \mathrm{S}$ from the beginning of the institution -there was a need and there was a way. The existing ICTY B/C/S transcripts are not at all up to par to any of its audiences, but the good news is that it could be made in the $\mathrm{B} / \mathrm{C} / \mathrm{S}$ now even faster.

The lack of fully available court transcripts in the languages of the former Yugoslavia does put a damper on the whole ICTY legacy. Whereas the ICTY parties to the proceedings put

\footnotetext{
${ }^{41}$ Fidahić, Linguistic Justice at the ICTY, Appendix 5. First mentioned in footnote 25.

42 OSCE, Supporting the Transition Process. First mentioned in footnote 37.

${ }^{43}$ Om3ga Solutions, Daktilograf, n.d., accessed September 21, 2021, https:/ / daktilograf.me/.
} 
up a fair fight and fought each other with facts enabling judges to establish indisputable historical record of the events in the former Yugoslavia during the wars, the ICTY Registry, CLSS, failed to inform the former Yugoslavia about that indisputable record in their language. Although having legal recourse, the CLSS managers failed at their due diligence to inform language policies which led to the lack of full B/C/S transcripts with effect on defendants, defense, victims and witnesses, and the legal colleagues and posterity in the former Yugoslavia. There is a discrepancy in the quantity of ICTY B/C/S transcripts delivered to the local judiciaries in the former Yugoslavia and that reported to the donors; they are reported to be inadequate by the end-users. ICTY B/C/S transcripts remain the last chance for the former Yugoslav populace to finally heal from nationalist disease eating away at their ordinary citizens, academia, and politics. It would be the best if the judges took the reins and made sure ICTY B/ $\mathrm{C} / \mathrm{S}$ transcripts are completed and delivered in full; only then can it be said their legacy is full and complete.

\section{Bibliography}

Brittain, Chloe. "Transcription Time Per Audio Hour: How Long Should Transcribing Actually Make?." Opal Transcription Services, n.d. Accessed September 21, 2021. https:// www.opaltranscriptionservices.com/transcription-time-per-audio-hour/.

Fall, Papa Louis and Yishan Zhang. Multilingualism in the UN System Organizations: Status of Implementation. Geneva: United Nations, Joint Inspection Unit, 2011. UN Doc. JIU/REP/ 2011/4. Accessed September 21, 2021. https://undocs.org/en/JIU/REP/2011/4.

Fidahić, Besmir. Linguistic Justice at the International Criminal Tribunal for the Former Yugoslavia. Newcastle upon Tyne: Cambridge Scholars Publishing, 2021.

Gaiba, Francesca. The Origins of Simultaneous Interpreting: The Nuremberg Trial. Ottawa: University of Ottawa Press, 1998.

Gordon, Gregory S. Atrocity Speech Law: Foundation, Fragmentation, Fruition. Oxford: Oxford University Press, 2017.

ICTY. “Annual Reports.” Accessed July 7, 2021. https://www.icty.org/en/documents/annualreports.

“Appeals Judgement, Tolimir: 08 April 2015." YouTube video, 01:12:37. Uploaded April 8, 2015. Accessed July 2, 2021. https://youtu.be/HE8xMksBd1w.

. “Arrêt, Milan Lukić \& Sredoje Lukić: 4 Décembre 2012." Uploaded April 8, 2015. Accessed July 2, 2021. https:/ / youtu.be/mM25Twga93U.

-----. Assessing the Legacy of ICTY: The Background Paper. The Hague: ICTY, 2010. Accessed July 7, 2021. https:// www.icty.org/sid/10292.

-------. "Court Transcript in Šešelj." March 25, 2003. Accessed July 2, 2021. https:// www.icty.org/x/cases/seselj/trans/en/030325IA.htm.

--art "Court Transcript in Tolimir." September 14, 2007. Accessed July 2, 2021. https:// www.icty.org/x/cases/tolimir/trans/en/070914SC.htm.

. "Organization of the ICTY." Accessed July 7, 2021. https://www.icty.org/en/about/ tribunal/organisational-chart.

-------. Practice Direction On Procedure For The Proposal, Consideration Of And Publication Of Amendments To The Rules Of Procedure And Evidence Of The International Tribunal (as amended). January 24, 2002. IT/143/Rev.2.

--------. Rules Of Procedure And Evidence. July 8, 2015. IT/32/Rev.50.

--------. Updated Statute of the International Criminal Tribunal for the Former Yugoslavia. September 2009.

Jelačić, Nerma. Legacy of the ICTY in the Former Yugoslavia. The Hague: ICTY Outreach Programme, 2013.

Jobs in Zambia (blog). "International Criminal Court (ICC), Court Reporter-English, The Hague, 2013, Vacancy Announcement No: 3031EE-RE.” Accessed September 21, 2021. http:// zambiajobs.blogspot.com/2013/11/ court-reporter-english-hague.html. 
Meron, Theodor. The Making of International Criminal Justice: The View from the Bench: Selected Speeches. Oxford: Oxford University Press, 2011.

Om3ga Solutions. Daktilograf. n.d. Accessed September 21, 2021. https:/ / daktilograf.me/.

Organization for Security and Co-operation in Europe (OSCE). Supporting the Transition Process: Lessons Learned and Best Practices in Knowledge Transfer: Final Report. Warsaw: September 2009. Accessed September 21, 2021. https://www.icty.org/x/file/About/ Reports\%20and\%20Publications/report supporting transition en.pdf.

United Nations. Seventh Annual Report of the Internal Tribunal for the Prosecution of Persons Responsible for Serious Violations of International Humanitarian Law Committed in the Territory of the Former Yugoslavia since 1991. August 7, 2000. A/55/273-S / 2000/777.

------. Report of the Internal Tribunal for the Prosecution of Persons Responsible for Serious Violations of International Humanitarian Law Committed in the Territory of the Former Yugoslavia since 1991. August 23, 1995. A/50/365-S/1995/728.

-------. Report of the Internal Tribunal for the Prosecution of Persons Responsible for Serious Violations of International Humanitarian Law Committed in the Territory of the Former Yugoslavia since 1991. August 16, 1996. A/51/292-S/1996/ 665.

---------. Report of the Internal Tribunal for the Prosecution of Persons Responsible for Serious Violations of International Humanitarian Law Committed in the Territory of the Former Yugoslavia since 1991. September 18, 1997. A/52/375-S/1997/729.

United Nations Careers. "Verbatim Reporters." United Nations. Accessed July 7, 2021. https:// careers.un.org $/ \mathrm{lbw} /$ home.aspx?viewtype=LCEFD\&FId=4.

United Nations Interregional Crime and Justice Research Institute (UNICRI). ICTY Manual on Developed Practices. The Hague: UNICRI Publisher, 2009. Accessed 21 September 2021. https://www.icty.org/x/file/About/Reports\%20and\%20Publications/ manual developed practices/icty manual on developed practices.pdf.

Manual on International Criminal Defence: ADC-ICTY Developed Practices Documents: Within the Framework of the War Crimes Justice Project. The Hague: UNICRI Publisher, 2011. Accessed July 7, 2021. https://www.icty.org/x/file/About/ Reports\%20and\%20Publications/manual developed practices/ ADC ICTY developed practices en.pdf. 